University of Minnesota Morris Digital Well

University of Minnesota Morris Digital Well

Winter 2009

\title{
Moses, Man of Oppression: A Twentieth-Century African American Critique of Western Theocracy
}

\author{
Michael Lackey \\ University of Minnesota Morris, lacke010@morris.umn.edu
}

Follow this and additional works at: https://digitalcommons.morris.umn.edu/eng_facpubs

Part of the Modern Literature Commons

\section{Recommended Citation}

Lackey, Michael. 2009. "Moses, Man of Oppression: A Twentieth-Century African American Critique of Western Theocracy." African American Review 43.4: 577-588.

This Article is brought to you for free and open access by the Faculty and Staff Scholarship at University of Minnesota Morris Digital Well. It has been accepted for inclusion in English Publications by an authorized administrator of University of Minnesota Morris Digital Well. For more information, please contact skulann@morris.umn.edu. 


\title{
Moses, Man of Oppression: A Twentieth-Century African American Critique of Western Theocracy
}

\author{
Michael Lackey
}

This is an Accepted Manuscript of an article published by The John Hopkins University Press in African American Review in Winter 2009, available online: https://muse.jhu.edu/article/451648

If Allen Dwight Callahan, author of The Talking Book: African Americans and the Bible, is to be believed, African Americans monolithically revere Moses as a "venerable ideal of African American leadership" (98), since he provided oppressed people with the perfect model for setting the captives free. So instrumental was the figure of Moses in the project of emancipating blacks that he has been considered almost as important as Jesus, for as James Cone claims in For My People: Black Theology and the Black Church: "black Christians have always known that the God of Moses and of Jesus did not create them to be slaves or second-class citizens in North America" (8). No doubt Moses figured prominently in nineteenth-century African American literature and culture, as can be seen in traditional spirituals ("Thus saith the Lord, bold Moses said, / Let my people go" ["Go Down, Moses"]), Frances Harper's Moses: A Story of the Nile (Moses brings about the "great deliverance" [1.153] of the enslaved and the oppressed) and Paul Laurence Dunbar's "An Ante-Bellum Sermon" ("de Lawd will sen' some Moses / Fu' to set his chillun free" [11. 30-31]). ${ }^{1}$ But there was a palpable split in black community's representation of Moses in twentieth-century African American literature, which poses a substantive challenge to Callahan's monolithic interpretation. For instance, in a letter to Carl Van Vechten about what she considered her most important work, Herod the Great, Zora Neale Hurston claims that "Moses forced" his laws on the ancient Hebrews "by terror and death" and that "Moses was responsible for the actual death of at least a half million of the people in his efforts to force his laws upon them" (Zora 529). So ruthless, monomaniacal, and fanatical was Moses that Hurston refers to him as a "dictator" (530), a description that certainly had profound implications in 1945, just after the end of World War II, when Hurston penned the letter. Hurston's remarks about Moses are interesting in themselves, but they are even more significant in relation to the black community's treatment of Moses and Exodus. Let me state my point more directly by challenging Callahan's monolithic interpretation of African Americans and Moses. Callahan claims: "For African Americans, Moses was more than an expert magician or antimagician. He was, first and foremost, a leader of his people. Moses personifies leadership as divine vocation" (93). Based on her 1945 letter, Hurston certainly does not subscribe to the view that Moses was a divinely inspired leader. Indeed by linking Moses with "terror and death" and by calling him a "dictator," Hurston indicates how he can be defined as the perfect enabler of an oppressive and unjust political regime, a position that directly contradicts Callahan's interpretation of black appropriation of the Exodus myth. As I will demonstrate throughout this essay, Hurston was not alone in thinking of the Moses figure as a potentially dangerous and ultimately destructive model of a political leader.

In James Baldwin's Go Tell It on the Mountain, Gabriel Grimes's mother has clearly internalized the standard view of the Exodus story in which "the national quest of Israel became 
an analog for the aspirations and aims of African Americans" (Glaude 54). As Gabriel's sister Florence paraphrases her mother's view, God wants the black community to "hear, and pass thereafter, one to another, the story of the Hebrew children who had been held in bondage in the land of Egypt; and how the Lord had heard their groaning, and how His heart was moved; and how He bid them wait but a little season till He should send deliverance" (70). In Notes of a Native Son, Baldwin explains that "the Negro identifies himself almost wholly with the Jew." In fact, Baldwin writes, "[t]he more devout Negro considers that he is a Jew, in bondage to a hard taskmaster and waiting for a Moses to lead him out of Egypt" (55). But in his prefatory comments to this claim, Baldwin offers a psychological rather than a theological explanation for black appropriation of the Exodus myth: "religion operates here as a complete and exquisite fantasy revenge: white people own the earth and commit all manner of abomination and injustice on it; the bad will be punished and the good rewarded, for God is not sleeping, the judgment is not far off " (54). For Baldwin, black devotion to Moses is founded on wish-fulfillment, based on a promise for happiness as well as a desire for revenge. More important, the Mosaic promise of freedom is nothing more than the seething product of an overheated imagination, for as Baldwin claims in a 1969 essay, "the Moses they sent us, whatever his ancestry, certainly failed to set the captive children free" ("Negroes" 11).

What we find among many twentieth-century African American writers is a more complicated and ambivalent attitude towards Moses. For instance, in a 1997 speech, Alice Walker acknowledges the black community's devotion to and appropriation of Moses: "In the black church, we have loved and leaned on Moses, because he brought the enslaved Israelites out of Egypt. As enslaved and oppressed people, we have identified with him so completely that we have adopted his God" (297). But for Walker, this devotion to Moses is not a virtue; it is instead a major vice. The problem with Moses is that he believes in a God who does not love black people, which is why Walker, after explaining black devotion to Moses, concludes: "It is fatal to love a God who does not love you" (297). What explains the progression from the nineteenthcentury view of Moses as the Great Deliverer, to the mid-twentieth-century view of Moses as failed emancipator, to the late twentieth-century view of Moses as a man devoted to a God who does not love black people?

Richard Wright gestures towards an answer in the introduction to White Man, Listen! in cautioning his readers to be skeptical of anyone who plays the role of Moses: "I'm no Moses and, as one great and shrewd American once said, if some Moses should lead you into the Promised Land, some other Moses, equally adroit and persuasive, could just as easily lead you out again" (646). Moses is ultimately an empty signifier, a semiotic vacuity that could be used to liberate the oppressed but also to re-enslave the liberated. In an unpublished lecture version of the first chapter from White Man, Listen!, Wright explains in more detail the reasons why people should be so reluctant to embrace Moses as a political figure:

This platform is not Mount Sinai and I have no Ten Commandments to hand down to you for your salvation. I'm not Moses to lead you into the Promised Land. And, if I were you, I'd be extremely doubtful of any Moses who promises to lead you into that Promised Land, for, if a Moses should lead you into that Promised Land, another Moses could just as easily lead you right out again. In this connection I'd advise you to read most carefully the terrifying and melancholy utterances of a certain Comrade Khrushchev who recently explained to the doting and faithful millions how much murder a Moses can commit. ${ }^{2}$ 
Written between 1951 and 1956, long after Wright had rejected communism, Wright's reference to Khrushchev should not be considered an endorsement of Soviet politics. ${ }^{3}$ Wright is extremely critical of Khrushchev later in the lecture. But he is trying to underscore the fact that the image of Moses as a model of political leadership can be as dangerous as it is empowering. In other words, blacks can deploy the Moses myth in order to achieve liberation, but they must understand that in valorizing Moses they are also making it possible for the Moses figure to be used to justify their subjugation and annihilation.

More than anything else, what compelled so many black writers to reassess the Moses myth was the theology of Western imperialism, and no one articulates that theology more cogently than Rudyard Kipling. It was in the late 1890s, when King Leopold II was colonizing the Congo and the United States was annexing the Philippines, that Kipling published "The White Man's Burden," a poem exhorting U. S. citizens to bind their "sons to [the] exile" (1. 3) of colonial rule in order to liberate the "Half-devil and half-child" (1. 8) of non-Christian nations, such as the Philippines, from their "heathen Folly" (1. 23). In other words, Kipling considered the United States to be in a similar position as Great Britain. As he claims in his poem, "Recessional," the Chosen Race is special because it has privileged epistemological access to the Law. Within this framework an imperial power, which stands beneath the "awful Hand" (1. 3) of the "God of our fathers" (1. 1) holds "Dominion" (1. 3) over the "lesser breeds" (1. 22), who are "without the Law" (1. 22).

For early twentieth-century writers who were concerned with social justice for all people irrespective of race, "The White Man's Burden" and "Recessional" were two of the most offensive and destructive poems ever written, because they forcefully and cogently formulated the religious philosophy on which the West's racist political agenda rested. So influential were the poems that most black writers, when referencing them, did not even mention Kipling by name. For instance, in an editorial titled "The Passing of Jack Johnson," James Weldon Johnson says: "One of the delusions fostered by the Anglo-Saxon is that white men are superior to those of 'lesser breed' not only intellectually, but also in physical strength and stamina" (615). In "The Souls of White Folk" chapter from Darkwater, W. E. B. Du Bois denounces the U. S. for becoming like Europe by committing the "worst sin against civilization. She aspires to sit among the great nations who arbitrate the fate of 'lesser breeds without the law"' (464). In Discourse on Colonialism, Aimé Cesaire mentions "the famous white man's burden" $(60,73)$ twice to indicate the powerful effect of Kipling's rhetoric in the cause of colonization. In White Man, Listen! Wright alludes to Kipling's poem "Recessional" in order to indicate the kind of people Africans are up against in their struggle for freedom: "he [a national revolutionary] is faced with a Western world that stubbornly clings to the idea that God Himself has given it the right to rule the 'lesser breed'" (687). Also, in The Color Curtain, a report on the 1955 Bandung Conference of Asian and African leaders in Indonesia, Wright, without mentioning Kipling's name, asks a number of people the connection in which they "first heard the phrase 'White Man's Burden'" (446). It should come as no surprise that Baldwin uses a stanza from "The White Man's Burden" as an epigraph to his inflammatory book, The Fire Next Time.

For black writers, what must have been particularly galling about Kipling's theologically inflected poetry was his placement of the white man in the position of Moses. For example, in "The White Man's Burden," Kipling suggests that nonwhites are chosen people, but they are like the ancient Hebrews who have become inured to their enslaved lives in Egypt. According to this 
interpretation, the white man is positioned within the biblical text in relation to Moses, who selflessly serves the spiritual needs of the chosen race but who receives nothing but resistance and derision from the momentarily benighted chosen people:

Take up the White Man's burden-

And reap his old reward:

The blame of those ye better,

The hate of those ye guard-

The cry of hosts ye humour

(Ah, slowly!) toward the light:-

"Why brought ye us from bondage,

Our loved Egyptian night?" (11. 33-40)

Kipling uses the Exodus myth, and even places the colonized Other in the position of the Chosen People, but by placing the white man in the position of Moses and by conceiving of the colonial Others as ancient Hebrews within an Egyptian night, he was able to use the Moses story, and even the black interpretation of that story, to justify the white man's domination of the "lesser breeds." In a twisted sense, Kipling's intellectual move in "The White Man's Burden" is brilliant, and it reflects a clearer formulation of Europe's political justification for imperialism. In the eighteenth and nineteenth centuries, whites in both Europe and the United States dubbed blacks Canaanites or children of Ham, thus reducing them to nonchosen people in order to justify the perpetual domination and violation of nonwhites. But by characterizing blacks as the Chosen People who are simply steeped in an Egyptian night, Kipling was able to honor nonwhites with a chosen title while still justifying an imperial relation. What I am trying to demonstrate here is that black writers, acutely aware of the intricate logic of the Bible's Exodus myth, were able to recognize the theology on which Kipling's nation-state politics were based, which explains why black writers, with stunning regularity, spent so much time referencing Kipling.

It is within this context that we begin to witness among many black intellectuals a turn away from Christianity and the Bible. For example, in the short story "Father and Son," Langston Hughes's narrator says: "Poor over-worked Jesus! Somehow since the War, he hadn't borne that cross so well. Too heavy, it's too heavy! Only old people praise King Jesus any more" (230). What Hughes suggests in this story is that Bert, an illegitimate son of a white plantation owner, is one of many young, college-educated blacks to have rejected Christianity shortly after the Civil War. In The Autobiography of an Ex-Colored Man, published in 1912, James Weldon Johnson's unnamed narrator, who ultimately finds the Bible disappointing and careless (11), nonetheless berates "the progressive element among the colored people" (82), because even though he considers Christianity to be on the wane, "it should never be forgotten that it was" prominent black preachers "who led the race from paganism, and kept it steadfast to Christianity all the long, dark years of slavery" (82). In other words, even though Christianity is in serious decline among black intellectuals, it has had a positive sociopolitical effect that needs to be honored and respected. By the 1920s, however, a viciously anti-religious mentality began to dominate, for as David Levering Lewis rightly claims, Harlem Renaissance writers "publicly denigrated the personnel and preaching of the Black Church" (xiv). For instance, in her 1928 novella, Quicksand, Nella Larsen examines how the Bible is used to justify first the superiority of the white community and the inferiority of black people and then the superiority of black men and the inferiority of black women. The novella opens with a white preacher who embellishes "his words with scriptural quotations" to support his claim that God has created blacks as 
"hewers of wood and drawers of water" (3), and it concludes with a black preacher, who also uses religious and biblical arguments, to justify his claim that female servitude is "an act of God" (125). ${ }^{4}$ In Larsen's 1929 novella Passing, Clare Kendry explains how her white relatives, who were "very religious" (158), had internalized a racist interpretation about "the sons and daughters of Ham" (159). In 1932, Langston Hughes published "Goodbye Christ," a poem in which the narrator claims that the Bible is a "swell story" that people have "ghosted" up in order to make money for popes and preachers. ${ }^{5}$ This vicious critique of Christianity and the Bible was especially pronounced among postcolonial thinkers. For example, in 1952, Frantz Fanon claimed in Black Skin, White Masks that "[a]ll forms of exploitation resemble one another. They all seek the source of their necessity in some edict of a Biblical nature" (Black 88). ${ }^{6}$ Also, in 1963, Baldwin claimed that the white man, when he colonized Africa, came with "the Bible," which is why "the African is still attempting to digest or to vomit up the Bible" (Fire 45).

What is ultimately behind this critique of Christianity and the Bible is the conviction that both can be used equally to empower and destroy - a point that Baldwin makes directly in The Fire Next Time, when he claims "that the vision people hold of the world to come is but a reflection, with predictable wishful distortions, of the world in which they live" (40). To illustrate his point, he indicates how whites and blacks appropriate the biblical text in very different ways: "In the same way that we, for white people, were the descendants of Ham, and were cursed forever, white people were, for us, the descendants of Cain" (40-41). ${ }^{7}$ While the Bible is a useful text for mobilizing an oppressed people to form a community in spiritual hope, it is also a useful text to mobilize an entitled people to form their community through brute domination of others. It was this oppressive component of Christianity and the Bible that compelled so many twentieth-century black writers to examine "the historical role of Christianity in the realm of power - that is, politics" (Fire 45), as Baldwin claims; what they discovered is that while the Bible empowered minority communities to experience some liberation, it simultaneously empowered dominant communities to expand their oppressive power.

With this model of the double-talking dimension of Christianity and the Bible in mind, we can now better understand and appreciate Hurston's harsh critique of Moses. What ultimately compelled Hurston to draw such a negative conclusion about Moses was her conviction that the Bible, and specifically the idea of the Chosen People, is an anti-democratic invention that, while easily manipulated in order to empower the oppressed and dispossessed, is more often than not an invaluable instrument in the political project of domination, exploitation, and extermination. In a letter to her former husband, Herbert Sheen, Hurston explains precisely why religious belief is fundamentally opposed to democracy. As an empiricist with formal training in anthropology, Hurston could not take the leap of faith: "Priests," she tells Sheen, "have lectured me on my intellectual approach instead of trusting all and everything to faith which my mental set-up will not allow" (699). If there were a God, Hurston reasons, "He should want humans to know certain things and to be guided by these principles" instead of "reveal[ing]" Himself and his principles "to so few" (699; original emphasis). That is, if there were a God, He or She should be epistemologically accessible to the democratic all rather than a chosen few:

The sun shines fully upon us everyday. Why cannot His will be as freely revealed since it is so important? And why allow Himself to be so easily misconstrued? Why so many religions? Why "reveal" Himself to an Arab in one light and to a Caucasian in another? And to a Hindu in still another and to a Mongol in still another? No, I cannot go for that. (699) 
Given that God is an amorphous idea accessible in very contradictory ways to a chosen few, Hurston concludes that God "is an anthropomorphic concept, made in man's own image" (699). ${ }^{8}$ At issue for Hurston is not what God is, but rather how God functions as an anthropomorphic projection, and specifically within a political context. ${ }^{9}$

Hurston addresses this idea of God as an empty signifier in considerable detail in her 1939 novel, Moses, Man of the Mountain. Early in the novel, Hurston underscores how the Godconcept, instead of having intrinsic meaning or specific content, is the psychological product of desiring humans. For instance, an Egyptian foreman, after gazing "at the drooping sun in awe," blurts out reverent words of praise to his God: "Ah, Horus, the golden god! Lord of both horizons. The weaver of the beginning of things!" (3). Having heard the foreman's spontaneous prayer, a Hebrew slave, Amram, offers a completely opposite interpretation: "Horus may be all those good things to the Egyptians, brother, but that sun-god is just something to fry our backs" (3). Later in this same chapter, Amram discusses the God-concept with another Hebrew slave, Caleb. Amram mentions how the Pharaoh passed laws prohibiting Hebrews from going into their temples, because he "says their gods ain't our gods" (5). Caleb explains what "a real empty feeling [it is] not to have no gods anymore" (5), so he proposes that they build a temple and worship Egyptian gods. But Amram responds by telling Caleb that the Egyptian "gods were made by Egyptians. Gods always love the people who make 'em" (6). This view of God as a solipsistic projection devastates Caleb: "Don't say that, Amram. That don't leave me no way to turn at all. Makes me feel like my insides been ripped out" (6). Caleb yearns for a God who sides with the oppressed and ensures social justice, but Amram suggests that God is simply a mental projection of His or Her human creators, and not surprisingly God loves the people who have created Him or Her.

Indeed, the God-concept is, according to Hurston, a communal projection of ideologically driven humans, and as such it frequently becomes a political instrument that justifies subjugation and when necessary, violence. As she claims in her essay "Crazy for this Democracy," "God has restated the superiority of the West. God always does like that when a thousand white people surround one dark one. Dark people are always 'bad' when they do not admit the Divine Plan like that" (166). Hurston's irony is unmistakable. She realizes that the God-concept has been put to effective use in the West in order to dominate, subjugate, and violate vulnerable people. In other words, Hurston understands that the God-concept has been the West's most important instrument in the project of dominating others. ${ }^{10}$ Specifically, Hurston considers the God-concept necessary for stratifying humanness, which is important in order to establish a master/slave political model and to justify acts of violence, including mass murder. She makes this point brilliantly in a letter to Henry Allen Moe from the Guggenheim Memorial Foundation. Hurston notes that in Western literature, the "Nordics" have consistently portrayed "Latins, Asiatics, Jews, Indians and Negroes [as] dying for love of the Nordics." But a couple sentences later, she imagines an alternative scenario: "I often wondered if they [the Nordics] realized what the 'lesser breeds outside the law' would do if they only had the guns" (502). That Hurston would quote Kipling's poem "Recessional" at this point is significant. For Kipling, the Chosen Race is special because it has privileged epistemological access to God's Law. Within this framework, what functions to determine humanness is the capacity to access God's Law, so for Anglo-Saxons, because they know the Law, they qualify as full-fledged humans, whereas for "Latins, Asiatics, Jews, Indians and Negroes," because they lack knowledge of the Law (what Hurston refers to as the "Divine Plan"), they are "lesser breeds." As official spokesperson for the virtues and necessity of 
imperialism in the name of God and His Law, Kipling intelligently articulates the theological justification for imperial domination. ${ }^{11}$

What troubles Hurston most about Moses and the Exodus myth is the political power dynamic that they establish. For instance, in the bowdlerized chapter from Dust Tracks, Hurston traces the state-sanctioned violence of her day back to the Chosen People-mentality of the Scriptures, what she considers the template for Western political systems. In this passage, Hurston sheds considerable light on her view of the theological basis of political oppression:

The Old Testament is devoted to what was right and just from the viewpoint of the Ancient Hebrews. All of their enemies were twenty-two carat evil. They, the Hebrews, were never aggressors. The Lord wanted His children to have a country full of big grapes and tall corn. Incidentally, while they were getting it, they might as well get rid of some trashy tribes that He never did think much of, anyway. With all of its figs and things, Canaan was their destiny. God sent somebody especially to tell them about it. If the conquest looked like bloody rape to the Canaanites, that was because their evil ways would not let them see a point which was right under their nose. So you had to drive it in under the ribs. King David, who invented the "protection" racket in those days before he was saved by being made king, was a great hero. He was a man after God's own heart, and was quite serviceable in helping God get rid of no-count rascals who were cluttering up the place.

(Dust 244-45)

Whoever controls the God-concept can stratify humanness, and since the Ancient Hebrews know the "Divine Plan" ("God sent somebody especially to tell them about it"), they qualify as the Chosen People, full-fledged humans who have the authority and right to rule and govern the "lesser breeds." By contrast, the Canaanites lack knowledge of the "Divine Plan" ("their evil ways would not let them see"), and as a consequence they are "no-count rascals," which God "never did think much of, anyway."

This critical view of the Exodus myth destabilizes the reified Christian interpretation. As Hurston suggests in the "Author's Introduction" of Moses, Man of the Mountain, her objective is to disrupt any stable conception of Moses. She begins by briefly describing "the common concept of Moses in the Christian world." But then in the next paragraph she claims that "there are other concepts of Moses abroad in the world," so many and so varied, in fact, "that some students have come to doubt if the Moses of the Christian concept is real" (xxiii). Of course, prominent scholars as varied as Robert E. Hemenway (260), Valerie Boyd (334) and Deborah E. McDowell (viii) have taken note of Hurston's destabilization of the Judeo-Christian conception of the Moses myth, but there has been a tendency with these interpretations to idealize Moses nonetheless. For instance, Deborah G. Plant, who has written in my estimation the most insightful and compelling interpretation of Moses to date, convincingly argues that "Hurston checks the biblical rendering of Moses as a Hebrew and the conventional American depiction of Moses as a white man" (138). In the novel, Moses finds inspiration and power in the Book of Thoth, a text to which Moses' mentor (Mentu), a Hebrew slave, introduces him. After locating and reading this text, Moses is significantly empowered. What is the significance of this text in the formation of Moses' character as a leader? Plant answers:

The book [of Thoth] exists, and Moses is empowered by reading it, as Mentu said he would be. But the introduction of the written word as a source of power contends with the assumption that the spoken Word of the Judeo-Christian God is thesource of all creativity, truth, meaning, and power. The spoken Word, as transcendental signified, is no longer absolute. The decentering of the 
presence, the ultimate referent, creates the possibility of a multiplicity of alternative world orders.

(139)

While many scholars are willing to call into question the standard Judeo-Christian interpretation of Moses, they seem less willing to challenge the view of Moses as a "venerable ideal of African American leadership." Here is what Plant concludes about Moses: "Hurston portrays him as the ideal to which other men should aspire" (127), for he is "the ideal individual" (128). Hurston indeed sees Moses "as the ideal leader who provides ideal leadership" (135).

There are good reasons to agree and disagree with Plant's interpretation of Moses. On the one hand, Moses is, by and large, treated as a positive albeit conflicted figure in Moses, Man of the Mountain, so Plant is right to offer such an idealistic interpretation of him. On the other hand, accepting the idea with which Hurston begins the novel in her "Author's Introduction," that there are varying traditions of the Moses myth, is a tacit admission that Kipling's white supremacist Moses is a legitimate possibility, which means that Moses would be anything but a "positive leader" for those "lesser breeds" who suffer from his autocratic rule. And it is such a view of Moses as an imperialistic tyrant that is at the core of Sigmund Freud's work on Moses, which Hemenway (257) acknowledges as one of Hurston's potential sources. Freud argues that Moses, an Egyptian, adopted the monotheistic religion of Ikhnaton, a young pharaoh of the Eighteenth Dynasty who forced a strict monotheism on his people. Ikhnaton, according to Freud, "raised the Aton religion to the official religion and thereby the universal God became the Only God; all that was said of other gods became deceit and guile" (72). Moses' adoption of a monotheistic God had huge political ramifications, for it created the universalistic thinking necessary for instituting imperialism: "In Egypt monotheism had grown — as far as we understand its growth — as an ancillary effect of imperialism; God was the reflection of a Pharaoh autocratically governing a great world Empire" (80). Put simply, the Mosaic "victory of monotheism in historical times" (169) set the political stage for twentieth-century imperialism, which is why Freud spends so much time examining "the establishment of monotheism among the Jewish people and its continuation into Christianity" (108). Kipling's white supremacist version of imperialism is incomprehensible without taking into account the Mosaic monotheistic myth.

In essence, Hurston and Freud agree that there are "contradictions to be found in the Bible in the characterization of Moses" (Freud 49). More important for Hurston, however, were the political ramifications of these contradictory views, which lead us to question the sense in which the Moses of my title in this essay is a man of oppression. My answer is that Moses, as the African American writers in this essay understand him, is an oppressive political figure not because he is intrinsically evil but because he is an empty signifier, as much an inspiration to oppressed blacks who yearn for freedom as to white supremacists who desire slaves. In other words, the problem with the Moses figure is that he is an empty signifier that can be used to construct an epistemologically inaccessible God, one that could be used to set the captives free, but also one that could be used to re-enslave the "lesser breeds" within an Egyptian night.

This idea that the God-construct is an anti-democratic, imperialistic invention explains why Hurston considers the figure of Moses a dangerous conceptual tool in the hands of political leaders. Within the context of Moses' God-state, individual humans are ultimately like lab mice, insignificant beings with which a political leader can experiment in order to determine the viability and practicality of his arbitrarily constructed system of law: 
It is all too evident that Moses did not care a fig for those Hebrew people. Moses had worked out an idea for a theocratic government, and the Hebrews were just so the available laboratory material. I am convinced that he thoroughly hated them after Sinai, if not before. At no time in the five books attributed to him, does he link himself with them in any way except as dictator. He says "these people" and to God "thy people." Never "my people." . . In every move, he shows himself as feeling superior to the people, and his scorn of them. There is not one word of love anywhere. (Zora 529-30)

Based on this account, instead of being the great liberator, Moses was actually a grand dictator, whose "theocratic government" is based on a feeling of superiority that comes from knowing God and His "Divine Plan."

Significantly, Hurston suggests in both her letter to Van Vechten and the bowdlerized chapter from Dust Tracks that Moses' conception of a "theocratic government" was the basis and foundation of the West's most ruthless and oppressive political regimes. For instance, in the letter to Van Vechten, Hurston specifically explains how the twentieth-century theocratic government is biblically based and functions to silence and disempower the nonchosen people. After outlining how twentieth-century political leaders have appropriated Moses' theocratic government and specified how those leaders have cast the Jews into the role of Canaanites - the "no-count rascals" of the text-Hurston describes the situation of Jews in a way that resembles the situation of blacks: "We have no written side of the people other than the direct testimony of their behavior recorded by their oppressors. And as one artist to another, you and I cannot but weep over the countless thousands of Jewish geniuses who must have lived and died unheard" (Zora 530). After discussing "the sufferings of the muted people," Hurston concludes: "It is a terrible picture and equal to what has gone on in our Christian lands under the Popes \& Preachers" (Zora 531). ${ }^{12}$

Put simply, the contemporary "Western World" has, according to Hurston, appropriated Moses' Chosen-People theology and has thereby justified violence against nonchosen people. In Dust Tracks, for instance, she notes that "[t]he New Testament is not quite so frank [as the Old Testament], but it is equally biased. Paul and the disciples set up a New Order in Palestine after the death of Jesus, but the Jews gave it nothing but their shoulder-blades. So now the Orthodox Jew became a manifest enemy of right" (245). Hurston's point is not simply that the early church was anti-Semitic; she is trying to explain the contemporary political situation, for as she claims just a few paragraphs later: "Those Jews who would not accept Christianity look very bad in the New Testament. And two thousand years have gone by and all the Western World uses the sign of the Cross, and it is evident that the Jews are not the only ones who do not accept it" (245-46). Two thousand years later Christianity's Chosen-People theology, Hurston suggests, is now the Western world's basis for subjugating and violating Jews and many others. In her letter to Van Vechten, Hurston outlines how Moses' Chosen-People mentality is specifically responsible for inculcating a desire to get rid of the Jews. As she claims, "our present-day prejudices" against the Jews are "what is taught in Sunday Schools" (532). ${ }^{13}$ She even claims that she had been "taught of the evil ways of the Jews. So evil that God had to do away with them. They are meant to be kicked around" (532). Her rhetoric at this point recalls her discussion of the ancient Hebrews, who dub the Canaanites "evil" and "no-count rascals." In other words, to understand the psychology that justifies the horrid treatment of the Jews in her day, we must take 
into account the source of this thinking, which can be traced back to Moses"'theocratic government."

We are now in a position to take issue with one of the main claims in Callahan's book, which is that "Moses continued to be an evocative ideal in African-American representations of authentic leadership in the twentieth century" (94). There have been, to be sure, many prominent twentieth-century African Americans for whom Moses remained an ideal spiritual and political leader, such as Martin Luther King, Albert Raboteau, Jesse Jackson, and others. ${ }^{14}$ But for every notable African American who considered Moses an ideal leader, there were others who considered him a deadly political figure. We have Sylvester Johnson to thank for redirecting our thinking about the role religion has played in the complex interplay between the construction of an American identity and the formation of race relations. But what so many studies of religion consistently ignore, Johnson astutely argues, is the sociopolitical role the Judeo-Christian religion has played in disfiguring non-chosen people (111). Hurston, Baldwin, Wright, and Walker would certainly agree with Johnson, but they would trace the structure of disfigurement back to Moses, the originator of a Chosen-People mentality that has been effectively used to justify subjugating, violating, and even exterminating the "lesser breeds" that God wanted to get rid of anyway. For those prominent twentieth-century African Americans who have traced the history of Western oppression back to the Chosen-People mentality of Exodus, Moses is not just one criminal among many others. He is the originary criminal, the parent of all our Western political woes. It should therefore come as no surprise that Walker, just after telling her reader that Moses worships a God that does not love black people, concludes: "We have been beggars at the table of a religion that sanctioned our destruction" (297).

\footnotetext{
Notes

${ }^{1}$ For excellent discussions of the role Moses played in the political project of African American liberation, see John Ernest, Liberation Historiography: African American Writers and the Challenge of History, 1794-1861 (Chapel Hill: U of North Carolina P, 2003); Albert J. Raboteau, Canaan Land: A Religious History of African Americans (New York: Oxford UP, 2001); Wilson Jeremiah Moses, Black Messiahs and Uncle Toms: Social and Literary Manipulations of a Religious Myth (University Park: Pennsylvania State UP, 1982); David Howard-Pitney, The African American Jeremiad: Appeals for Justice in America (Philadelphia: Temple UP, 2005); Jacquelyn Grant, White Women's Christ and Black Women's Jesus: Feminist Christology and Womanist Response (Atlanta: Scholars, 1989); and Glaude.

${ }^{2}$ I take this quotation from one of the lecture versions of "some psychological traits of oppressed people," which would eventually become the first chapter of White Man, Listen! This lecture is in the Richard Wright Papers, Box 65, folders 767-69, Beinecke Rare Book and Manuscript Library, Yale University. I want to thank the Beinecke Library for giving me access to these materials.

${ }^{3}$ In the introduction to Black Power, Wright acknowledges that he was a member of the Communist Party from 1931 until 1944. Wright ultimately rejected Marxist communism because, as he claims, it was changing the "world in a manner that granted me even less freedom than I had possessed before" (10).

${ }^{4}$ For a more extensive analysis of Larsen's critical view of religion, see chapter three of Michael Lackey, African American Atheists and Political Liberation: A Study of the Socio-Cultural Dynamics of Faith (Gainesville: UP of Florida, 2007).

${ }^{5}$ For an excellent discussion of the controversy surrounding Hughes's publication of this poem, see Arnold Rampersad, The Life of Langston Hughes, vol. 1 (New York: Oxford UP, 1986), 390-95.

${ }^{6}$ For a more extensive analysis of Fanon's critique of religion and the God-concept, see Michael Lackey, "Frantz Fanon on the Theology of Colonization," Journal of Colonialism \& Colonial History 3.2 (Fall 2002): 1-29.

${ }^{7}$ For an excellent discussion of the dehumanizing potential of biblical discourse, see S. Johnson.

${ }^{8}$ This view of God as an anthropomorphic construction is most intelligently articulated in Ludwig Feuerbach, The Essence of Christianity (1855), George Eliot, trans. (Buffalo, NY: Prometheus Books, 1989);
} 
Friedrich Nietzsche, Anti-Christ (1895), R. J. Hollingdale, trans. (New York: Random House, 1989), On the Genealogy of Morals (1887), Walter Kaufmann and R. J. Hollingdale, trans. (New York: Random House, 1989), and Twilight of the Idols (1889), R. J. Hollingdale, trans. (New York: Random House, 1989); and Sigmund Freud, The Future of an Illusion (1927), James Strachey, trans. (New York: Norton, 1961). For the best discussion of the God-concept as anthropomorphic construction within the context of race, see J. Saunders Redding, On Being Negro in America(Indianapolis: Charter Books, 1962).

${ }^{9}$ In the "Religion" chapter (193-203) of Dust Tracks, Hurston confessed that she rejected Christianity at a very young age, and in this same chapter, she claims that God is but "a creature" of our "own minds" (201).

${ }^{10}$ It is worth noting that African American writers consistently rejected the standard view that the West was undergoing a radical process of secularization. As Appiah claims, "[s]ecularization seems hardly to be proceeding: religions grow in all parts of the world; more than 90 percent of North Americans still avow some sort of theism" (145). Central to Appiah's argument is a crucial distinction between academics and nonacademics. Appiah concedes that secularization may have occurred in the "world of the higher academy and a few islands of its influence" (145), but as for everyday citizens, secularization has simply not occurred. It is this religious view of the modernist body politic that led Wright to conclude in an early lecture version of his book White Man, Listen!: "The Mid-Twentieth Century finds more active religion on earth than at any time since 1455 ! This is a startling fact and I do not think that it has been sufficiently weighed, studied, and appreciated." This lecture was titled: "TRADITION AND INDUSTRIALIZATION: The Plight of the Tragic Elite in Africa," and it was delivered "at the First Conference of Negro Artists and Intellectuals organized by the society of African Culture in Paris in September 1956," a lecture that would eventually become a chapter in White Man, Listen! This lecture is in the Richard Wright Papers, Box 65, folders 772-73, Beinecke Rare Book and Manuscript Library, Yale University.

${ }^{11}$ I say that he was official spokesperson because the Swedish government rewarded Kipling for his religiously inflected political poetry with the Nobel Prize for Literature in December 1907. C. D., the official spokesperson for the Nobel Committee, specifically praised Kipling for his religious convictions ("For Kipling, God is first and foremost Almighty Providence, termed in Life's Handicap a 'Greet [sic] Overseer'. The English as a nation can well appreciate these conceptions, and Kipling has become the nation's poet" [294]) and his imperialist agenda ("Kipling reveals himself as an imperialist, a citizen of a world-wide empire. He has undoubtedly done more than any other writer of pure literature to draw tighter the bonds of union between England and her colonies" [292]).

${ }^{12}$ For a more extensive analysis of Hurston's critique of Moses' Chosen People mentality, see Michael Lackey, African American Atheists and Political Liberation: A Study of the Socio-Cultural Dynamics of Faith (Gainesville: UP of Florida, 2007), 117-41.

${ }^{13}$ In The Fire Next Time 36-38, Notes of a Native Son 55-60, and "Negroes Are Anti-Semitic Because They're Anti-White," Baldwin also examines this distinctly religious hatred of the Jew within an American context.

${ }^{14}$ For a discussion of some prominent twentieth-century African Americans who continue to revere Moses as an ideal political leader, see Callahan 89-101. 


\section{Works Cited}

Appiah, Kwame Anthony. In My Father's House: Africa in the Philosophy of Culture. New York: Oxford UP, 1992.

Baldwin, James. The Fire Next Time. 1963. New York: Vintage Books, 1991.

- Go Tell it on the Mountain. 1952. New York: Dell, 1981.

__. "Negroes Are Anti-Semitic Because They're Anti-White." 1967. Black Anti-Semitism and Jewish Racism. New York: Richard W. Baron, 1969. 3-12.

- Notes of a Native Son. 1955. Boston: Beacon, 1964.

Boyd, Valerie. Wrapped in Rainbows: The Life of Zora Neale Hurston. New York: Scribner, 2003.

Callahan, Allen Dwight. The Talking Book: African Americans and the Bible. New Haven: Yale UP, 2006.

C. D. "The Nobel Prize for Literature, 1907." Kim. By Rudyard Kipling. 1901. Ed. Zohreh T. Sullivan. New York: Norton, 2002. 290-96.

Cone, James. For My People: Black Theology and the Black Church. Maryknoll, NY: Orbis Books, 1984.

Du Bois, W. E. B. "The Souls of White Folk." 1920. W. E. B. Du Bois: A Reader. Ed. David Levering Lewis. New York: Henry Holt, 1995. 453-65.

Dunbar, Paul Laurence. "An Ante-Bellum Sermon." 1895. The Complete Poems of Paul Laurence Dunbar. New York: Dodd, Mead, 1913. 13.

Fanon, Frantz. Black Skin, White Masks. 1952. Trans. Charles Lam Markmann. New York: Grove Weidenfeld, 1967.

Freud, Sigmund. Moses and Monotheism. 1939. Trans. Katherine Jones. New York: Vintage, 1967.

Glaude, Eddie S., Jr. Exodus! Religion, Race, and Nation in Early Nineteenth-Century Black America. Chicago: U of Chicago P, 2000.

Harper, Frances Ellen Watkins. "Moses: A Story of the Nile." 1869. A Brighter Coming Day: A Frances Ellen Watkins Harper Reader. Ed. Frances Smith Foster. New York: Feminist, 1990. 138-66.

Hemenway, Robert E. Zora Neale Hurston: A Literary Biography. Urbana: U of Illinois P, 1980. Hughes, Langston. "Father and Son." 1934. The Ways of White Folks. New York: Vintage Classics, 1990. 207-55.

_. "Goodbye Christ." 1931. The Collected Poems of Langston Hughes. Ed. Arnold Rampersad. New York: Vintage Books, 1995. 166-67.

Hurston, Zora Neale. "Author's Introduction." Hurston, Moses xxiii-xxiv. . "Crazy for this Democracy." 1945. I Love Myself When I Am Laughing ... and Then Again When I Am Looking Mean and Impressive: A Zora Neale Hurston Reader. Ed. Alice Walker. New York: Feminist, 1979. 165-68.

—. Dust Tracks on a Road. 1942. New York: HarperPerennial, 1991.

- Moses, Man of the Mountain. 1939. New York: HarperPerennial, 1991.

- Zora Neale Hurston: A Life in Letters. Ed. Carla Kaplan. New York: Random House, 2002. Johnson, James Weldon. The Autobiography of an Ex-Colored Man. 1912. New York: Dover, 1995.

_. "The Passing of Jack Johnson." 1915. Writings: James Weldon Johnson. New York: Library of America, 2004.

Johnson, Sylvester A. The Myth of Ham in Nineteenth-Century American Christianity: Race, Heathens, and the People of God. New York: Palgrave Macmillan, 2004.

Kipling, Rudyard. "Recessional." Kipling, Rudyard Kipling 261-62.

—. Rudyard Kipling: The Complete Verse. London: Kyle Cathie, 2002. 
_. "The White Man's Burden." Kipling, Rudyard Kipling 257-58.

Larsen, Nella. Quicksand and Passing. 1928, 1929. Ed. Deborah E. McDowell. New Brunswick, NJ: Rutgers UP, 1988.

Lewis, David Levering. Introduction. The Portable Harlem Renaissance Reader. New York: Penguin, 1994. xiii-xli.

McDowell, Deborah E. "Foreword: Lines of Descent/Dissenting Lines." Hurston, Moses vii-xxii.

Plant, Deborah G. Every Tub Must Sit on Its Own Bottom: The Philosophy and Politics of Zora Neale Hurston. Urbana: U of Illinois P, 1995.

Walker, Alice. "The Only Reason You Want To Go To Heaven Is That You Have Been Driven Out Of Your Mind." 1995. By These Hands: A Documentary History of African American Humanism. Ed. Anthony B. Pinn. New York: New York UP, 2001. 289-98.

Wright, Richard. Black Power: A Record of Reactions in a Land of Pathos. 1954. Wright, Black Power: Three Books 1-428.

- Black Power: Three Books from Exile: Black Power; The Color Curtain; and White Man, Listen! New York: HarperPerennial, 2008.

- The Color Curtain: A Report on the Bandung Conference. 1956. Wright, Black Power: Three Books 429-630.

—. White Man, Listen! 1957. Wright, Black Power: Three Books. 
